Rapp. Grønlands geol. Unders. 99, 57-60 (1980)

\title{
SILURIAN CARBONATE MOUNDS OF SOUTH-EAST PEARY LAND, EASTERN NORTH GREENLAND
}

\section{J. E. Mabillard}

The carbonate mounds of Peary Land form part of a biohermal belt which can be traced east-west across North Greenland (Dawes, 1971, 1976). Carbonate mounds in central Peary Land (fig. 27, locality 1) have been described by Mayr (1976), Christie \& Peel (1977) and Lane \& Thomas (1979). This paper discusses previously undescribed carbonate mounds from south-east Peary Land (fig. 27, localities 2-11). In this region the widely spaced mounds form low hills and vary in size from domes tens of metres across to large biohermal complexes covering several square kilometres.

\section{The carbonate mound complex at locality 2}

This complex (fig. 28) was studied in detail during the 1979 field season. Here, the central carbonate mound facies is bounded to the south by the un-named Silurian limestone formation of Christie \& Peel (1977) and to the north, west and east by the un-named Silurian black shale formation. The relationships of these formations are shown in fig. 29.

The oldest exposed beds in section A-B (fig. 29) are assigned to member E of the un-named Silurian limestone formation (Christie \& Peel, 1977). These massive, dark

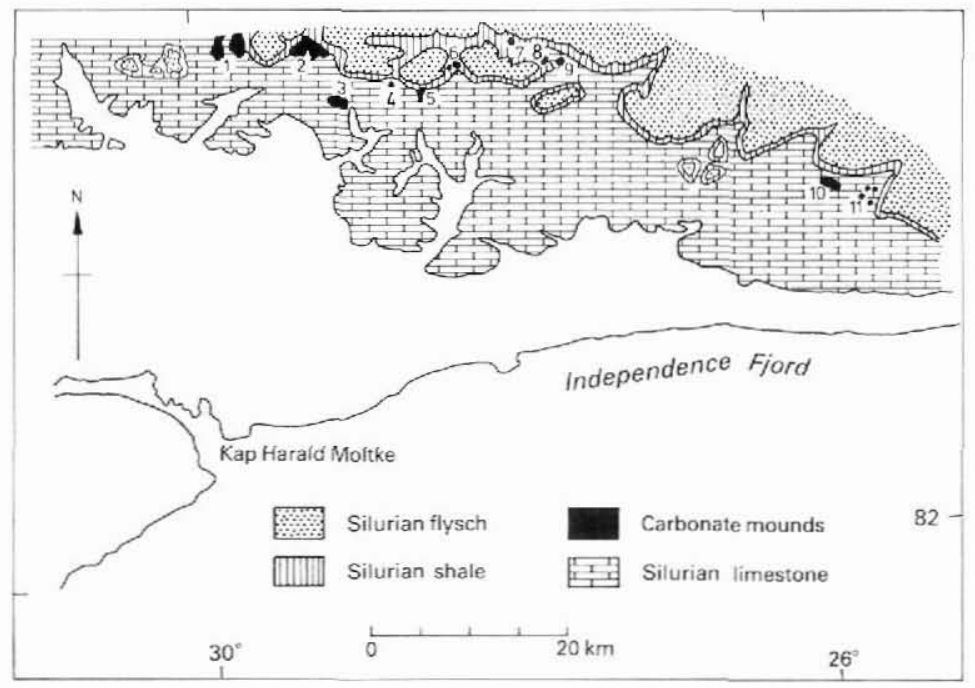

Fig. 27. Geological map of part of south-east Peary Land showing the distribution of carbonate mounds numbered 1-11. Regional geological map, see Rapp. Grønlands geol. 88 (1979). 

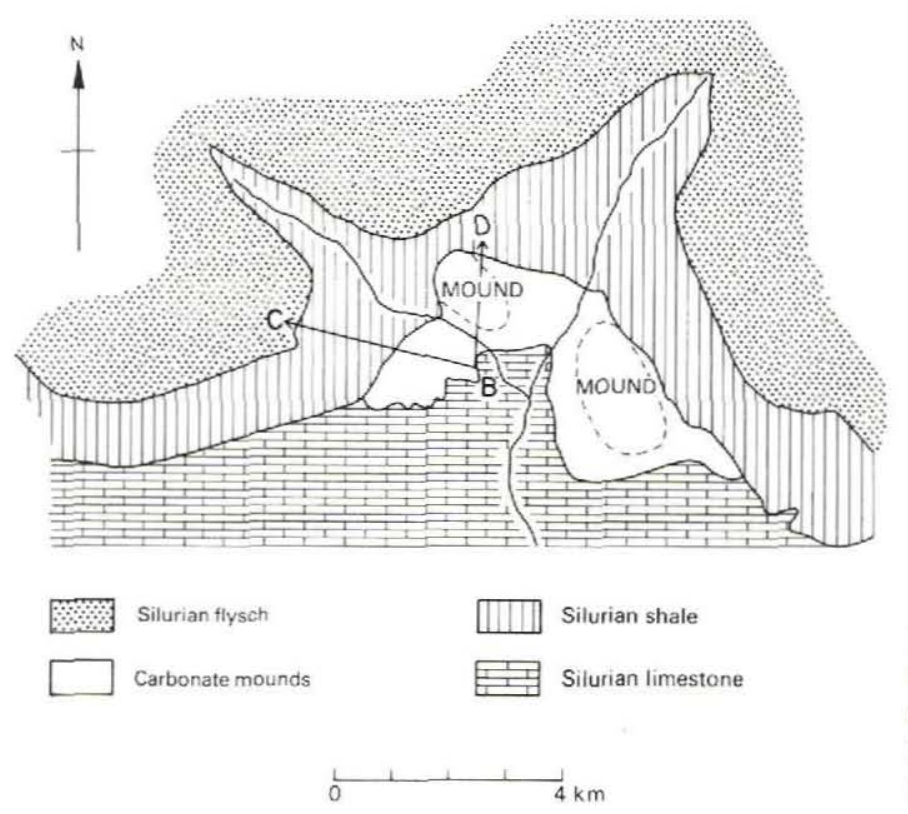

Fig. 28. Geological sketch map of carbonate mound complex at locality 2. B-C, $\mathrm{BD}$ traverses shown in fig. 29 .

weathering, mottled, nodular limestones are characterised by abundant spherical stromatoporoids, partially silicified fossils and horizons rich in chert. The overlying massive pale grey carbonate mound limestone lacks the partially silicified fossils and chert (Lane \& Thomas, 1979). At the top of the profile this limestone forms small mounds similar to those illustrated by Lane \& Thomas (1979).

A westwards traverse (B-C, fig. 29) shows these small mounds grading laterally into member $\mathrm{F}$ of the un-named Silurian limestone formation. This unit comprises thinly bedded nodular rubbly limestones with silty partings which are overlain further west by black graptolitic shales of the un-named Silurian black shale formation.

Two large carbonate mounds are developed in the complex; one to the north of section A-B, the other to the east (fig. 28). The northern mound, like all the other mounds in south-east Peary Land, has a core of massive pale grey stromatoporoidal limestone and a covering of unconsolidated crinoidal limestone.

Fossils are not evenly distributed in the carbonate mounds. The massive core limestones are poorly fossiliferous unlike the coarse crinoidal limestones covering the mounds which yield a rich and diverse fauna.

\section{Development of carbonate mounds in south-east Peary Land}

Lane \& Thomas (1979) stated that "the initiation of mound growth was certainly during the deposition of member E..." However, the oldest carbonate mound facies recorded from sections in south-east Peary Land (localities 2 and 3, fig. 27) were developing contem- 


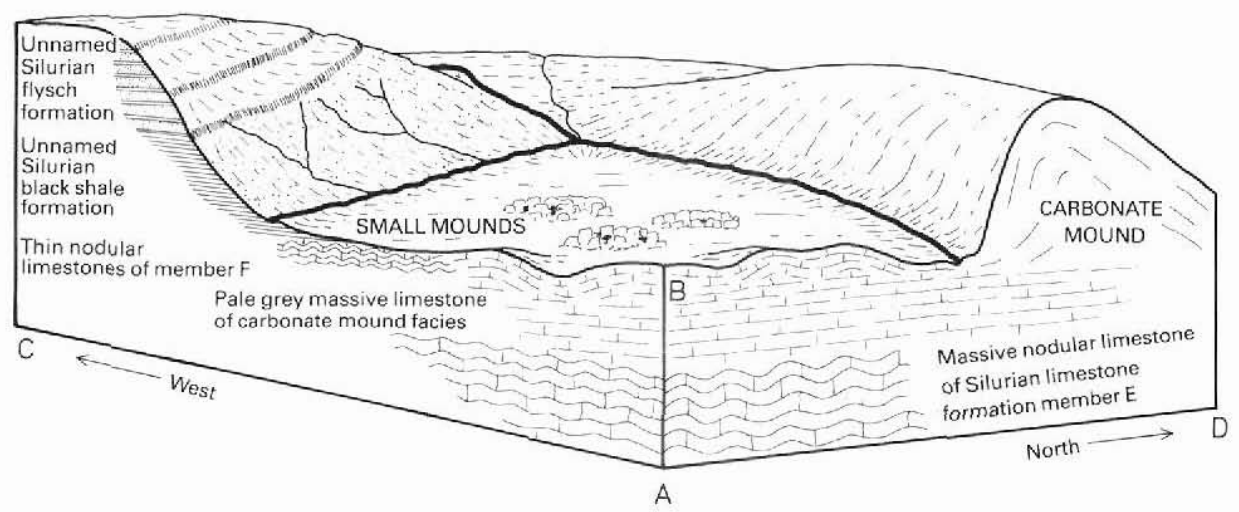

Fig. 29. Diagrammatic block section of locality 2 constructed from section A-B and traverses B-C and $\mathrm{B}-\mathrm{D}$ (see fig. 28). Diagram not to scale. Vertical section A-B is approximately $40 \mathrm{~m}$, traverse B-C is 4 $\mathrm{km}$ and traverse B-D is $3 \mathrm{~km}$.

poraneously with member $\mathrm{F}$. Carbonate mound growth may have continued on a reduced scale, during the deposition of the un-named Silurian black shale formation.

There is evidence to suggest that the burial of mounds, and hence possibly their growth during the deposition of the un-named Silurian black shale formation, was not contemporaneous throughout the region. This conclusion can be determined with reference to a 15 $\mathrm{m}$ thick turbidite unit developed in the middle of the un-named Silurian black shale formation and cropping out in the central part of the region. This unit comprises alternating thick-bedded, micaceous siltstone and grey, calcareous shales. The mound at locality 6 (fig. 27 ) is completely overlapped by shales and terminates a few metres below the turbidite. In contrast the highest bioclastic limestone of the mound at locality 8 contains patches of micaceous siltstone of the same lithology as the turbidite unit.

\section{Conclusion}

During the deposition of member $\mathrm{F}$ in late Llandovery times (Aldridge, 1979; Christie \& Peel, 1977; Lane \& Thomas, 1979), carbonate mounds were developing over quite extensive areas of south-east Peary Land. With the initiation of clastic sedimentation, in late Llandovery or early Wenlock times, carbonate deposition was greatly reduced and restricted to mounds which were "positive features of the sea floor" (Lane \& Thomas, 1979). With continued clastic influx carbonate deposition was reduced still further as smaller, less elevated mounds were swamped by shale. Hence, burial of the mounds occurred at different times thoughout the deposition of the un-named Silurian black shale formation. The largest mounds in the region (localities 2 and 3) may have continued to develop until the onset of flysch deposition.

Acknowledgements. Torben Sier Hansen is thanked for his invaluable field assistance. R. J. Aldridge, P. D. Lane and $\mathrm{H}$. Armstrong read the manuscript. 


\section{References}

Aldridge, R. J. 1979: An upper Llandovery conodont fauna from Peary Land, eastern North Greenland. Rapp. Grønlands geol. Unders. 91, 7-23.

Christie, R. L. \& Peel, J. S. 1977: Cambrian-Silurian stratigraphy of Børglum Elv, Peary Land, eastern North Greenland. Rapp. Grønlands geol. Unders. 82, 48 pp.

Dawes, P. R. 1971: The North Greenland fold belt and environs. Bull. geol. soc. Denmark 20, 197-239.

Dawes, P. R. 1976: Precambrian to Tertiary of northern Greenland. In Escher, A. \& Watt, W. S. (edit.) Geology of Greenland, 248-303. Copenhagen: Geol. Surv. Greenland.

Lane, P. D. \& Thomas, A. T. 1979: Silurian carbonate mounds in Peary Land, North Greenland. Rapp. Gronlands geol. Unders. 88, 51-54.

Mayr, U. 1976: Middle Silurian reefs in southern Peary Land, North Greenland. Bull. Can. Petrol. Geol. 24, 440-449. 